\title{
Use of Isolated Populations in the Study of a Human Obesity Syndrome, the Bardet-Biedl Syndrome
}

\author{
VAL C. SHEFFIELD \\ Department of Pediatrics, Howard Hughes Medical Institute, University of Iowa, Iowa City, IA 52240, U.S.A.
} \begin{abstract}
ABST
Bardet-Biedl syndrome (BBS) is a pleiotropic genetic disor-
der with the cardinal features of obesity, photoreceptor degeneration, polydactyly, hypogenitalism, renal abnormalities, and developmental delay. Other associated clinical findings in BBS patients include diabetes, hypertension, and congenital heart defects. The clinical diagnosis is based on the presence of at least four of the cardinal symptoms. BBS is recognized to be a genetically heterogeneous autosomal recessive disorder mapping to eight known loci. Positional cloning and candidate gene evaluation have resulted in the identification of six $B B S$ genes. Mutation of one of these genes, BBS6, also causes McKusickKaufman syndrome. The BBS6 gene is predicted to code for a protein with sequence similarity to the chaperonin family of proteins. The predicted $B B S 1, B B S 2, B B S 4, B B S 7$, and $B B S 8$
\end{abstract}

gene products do not seem to be molecular chaperones, on the basis of a lack of sequence similarity to the chaperonin family of proteins. The identification of BBS8 suggests a possible role in cilia function for BBS gene products. It remains to be determined whether the multiple BBS proteins are part of a multisubunit complex or do not directly interact with each other but are part of a common pathway. The study of BBS illustrates the value of using isolated inbred populations for the study of human genetic diseases and suggests strategies for facilitating the study of complex diseases and traits. (Pediatr Res 55: 908-911, 2004)
Abbreviations
BBS, Bardet-Biedl syndrome
MKS, McKusick-Kaufman syndrome

Hereditary diseases are often divided into two categories: those that display a simple Mendelian mode of inheritance and genetically complex disorders that do not display Mendelian inheritance. Mendelian disorders are the result of abnormalities of single genes, whereas complex disorders result from the interaction of at least two genes and/or genes and environmental factors. Mendelian disorders are individually rare but because $>10,000$ Mendelian disorders exist cumulatively have a major impact on health, particularly in the pediatric population. Complex disorders are individually common. With the completion of the Human Genome Project, the resources, opportunity, and challenge exist to assign function to all genes. One component of fully understanding gene function is to elucidate the involvement of individual genes in both monogenic and complex human diseases. One approach to better understand-

Received August 4, 2003; accepted January 9, 2004.

Correspondence: Val C. Sheffield, Ph.D., Department of Pediatrics, Division of Medical Genetics, Howard Hughes Medical Institute, University of Iowa, 4181 MERF, Iowa City, IA 52242; e-mail: val-sheffield@uiowa.edu

This work was supported in part by NIH grants EY11298, HL55006 and HL62178. VCS is an investigator of the Howard Hughes Medical Institute.

V.C.S. was the recipient of the Society for Pediatric Research 2003 E. Mead Johnson Award presented at the 2003 Annual Meeting of the Pediatric Academic Societies, Seattle, WA, U.S.A.

DOI: 10.1203/01.pdr.0000127013.14444.9c ing the molecular pathophysiology of complex disorders is to investigate Mendelian disorders that have phenotypic overlap with common complex diseases. Our laboratory has applied this strategy by studying Bardet-Biedl syndrome (BBS), a fascinating disorder once thought to be a single locus autosomal recessive disorder but now proved to be a genetically heterogeneous disease caused by multiple individual loci (16). Furthermore, there has been the recent suggestion that some cases of BBS result from the interaction of two or more loci (7-10). Because of the extensive genetic heterogeneity and possible genetic complexity, the study of BBS has benefited extensively from the availability of isolated human populations with this disorder.

In 1866, Laurence and Moon (11) described a syndrome that consisted of retinal degeneration, hypogonadism, mental retardation, and spastic paraplegia. Bardet (12) and Biedl (13) independently described a similar syndrome with the additional features of polydactyly and obesity. Subsequently, the disorder was referred to in the scientific and medical literature as Laurence-Moon-Biedl syndrome and Laurence-Moon-BardetBiedl syndrome. More recently, the Laurence-Moon-BardetBiedl syndrome has been considered to be two distinct disorders, Laurence-Moon syndrome and Bardet-Biedl syndrome (14). BBS is now recognized to have the primary features of 
obesity, polydactyly, pigmentary retinopathy, hypogonadism, renal anomalies, and developmental delay (14-17). Secondary features of BBS include diabetes, hypertension, and congenital heart defects $(16,18)$.

BBS is rare in most populations $(<1 / 100,000)$ but is reported to occur at a much higher incidence in some isolated inbred populations (19). It is hypothesized that genes involved in BBS may provide clues to the identification of biochemical and developmental pathways involved in common disorders and traits such as obesity, as well as provide additional understanding of normal developmental processes.

Genetic heterogeneity of BBS. Little was known about the cause of BBS, and no BBS genes or loci were identified until we began studying the disorder in isolated Bedouin Arab populations (1). The high rate of consanguinity in these populations results in an increase in the frequency of recessive genetic disorders (20). Three tribes with BBS were identified among the Bedouin Arabs of Israel. It was expected that the combined genetic information available in these three tribes would make it possible to map and positionally clone the BBS gene. Surprising, genetic mapping studies demonstrated that the disorder mapped to a different region of the human genome in each of the three Bedouin kindreds $(1,3,4)$. Work by us and others have now identified eight loci involved in BBS on chromosomes 11q13 (BBS1) (2), 16q21 (BBS2) (1), 3p (BBS3) (3), 15q22.3-q23 (BBS4) (4), 2q31 (BBS5) (5), 20p12 [BBS6; McKusick-Kaufman syndrome (MKKS)] (21, 22), 4p (BBS7) (23), and 14q32 (BBS8) (24). In addition, a pericentric inversion of chromosome 1 (p36.3;q23) has been reported to be associated with the BBS phenotype in multiple members of a single extended family (25).

Identification of BBS genes. Studies aimed at identifying the genes involved in BBS focused on refining the map positions of loci and the evaluation of positional candidate genes within the mapped intervals. Positional cloning of the BBS genes was initially hindered by the extensive genetic heterogeneity and by the inability to distinguish between causative loci based on phenotypic analysis. The identification of the first BBS gene resulted from the recognition that BBS shared phenotypic features of the McKusick-Kaufman syndrome (MKS). MKS is an autosomal recessive disorder characterized by vaginal atresia with hydrometrocolpos, postaxial polydactyly, and congenital heart defects $(26,27)$. The phenotypic overlap between MKS and BBS suggested that the gene that causes MKS would be a likely candidate gene for BBS. MKS was initially mapped to chromosome 20p12 using an Old Order Amish population (28). The causative gene was subsequently identified using positional cloning methods and given the name $M K K S$ (29). On the basis of phenotypic overlap between BBS and MKS, two groups independently identified a total of six mutations in BBS families, convincingly demonstrating that mutations in the $M K K S$ gene cause a small subset of BBS cases $(21,22)$. The $M K K S$ gene is now often referred to as $B B S 6$.

Our laboratory recently used positional cloning to identify the $B B S 1, B B S 2$, and $B B S 4$ genes (30-32). The use of population isolates and haplotype analysis was key to the identification of these genes by making it possible to map the individual loci and narrow the disease intervals even in the presence of extensive genetic heterogeneity. The identification of $B B S 1, B B S 2$, and $B B S 4$ was accomplished using populations from Puerto Rico and Bedouin populations from Israel. Subsequently, $B B S 7$ and $B B S 8$ were identified using a candidate gene approach based on the observation of some similarity with $B B S 2$ and BBS4, respectively $(23,24)$.

BBS gene function. Despite that six BBS genes now have been identified, little is known about the function of these genes and how they contribute to the pathogenesis of BBS. The known genes show very similar spatial and temporal patterns of expression. All are expressed early in development and continue to be widely expressed in adult tissues $(29,30-32)$. One of these genes, $B B S 6$, is predicted to code for a protein that has sequence similarity to the chaperonin family of proteins. Molecular chaperones are proteins that participate in the folding or assembly of nascent proteins into a higher order structure. The BBS6 protein has significant sequence homology to the $\alpha$ subunit of the Thermoplasma acidophilum thermosome (25), a prokaryotic chaperonin complex with structural similarity to a eukaryotic chaperonin called tailless complex polypeptide ring complex. On the basis of sequence homology, BBS1, BBS2, BBS4, and BBS7 do not seem to play a chaperonin role. These proteins may require BBS6 for proper folding and function.

The predicted BBS1, BBS2, and BBS7 proteins do not have sequence homology to other known proteins that provide significant clues to their function (30-32). BBS1 and BBS2 show modest sequence homology to each other over a limited region. Similarly, BBS2 and BBS7 show some sequence similarity. The predicted BBS4 protein shows weak homology to Olinked $\mathrm{N}$-acetylglucosamine transferase from several species (30). This sequence homology is limited to the TPR domains and is of unclear significance.

The recent discovery of $B B S 8$ seems to have provided an important clue to the function of BBS proteins. The predicted protein sequence of $B B S 8$ exhibits significant similarity to the pilF prokaryotic domain. In bacteria, the pilF gene has been shown to be involved in assembly of type IV pili, which mediate bacterial twitching motility (33). Ansley et al. (24) hypothesized that BBS8 and other BBS proteins are involved in cilia function. In support of this hypothesis, they demonstrated that BBS8 localizes to the basal body of ciliated cells, suggesting a role for BBS8 and other BBS proteins in ciliary assembly, maintenance, or function. It remains to be seen whether the multiple BBS genes will prove to code for proteins that are a part of a multisubunit complex or whether BBS proteins do not directly interact with each other but are part of a common biochemical or developmental pathway.

Genetic insights from monogenic disorders. The study of monogenic disorders can contribute to our understanding of complex disorders at several levels. First, the study of monogenic disorders that have phenotypic overlap with a common complex disorder can lead to identification of biochemical or developmental pathways involved in the common phenotype. For example, the study of BBS may lead to an understanding of pathways involved in regulation of weight control. Second, the study of Mendelian diseases can lead to improved understanding of genetic mechanisms that can play a role in genet- 
ically complex disease. Finally, the study of monogenic disorders can lead to improved strategies for studying genetically complex disorders. To date, the study of BBS has not established a unifying disease mechanism. However, this work has provided insights into the types of mutational events, genetic variation, study design, and strategies that are likely to contribute to the understanding of common complex disorders. Furthermore, this research has provided opportunities to gain insight into basic biologic processes and specific disease pathophysiology.

Mutation analysis of the $B B S 1$ gene indicated that nearly $40 \%$ of North American and European BBS patients have mutations in this gene, making it the most common cause of BBS, and identified a common mutation (M390R) shared by most BBS1 patients $(32,34)$. A surprisingly large region $(\sim 400$ $\mathrm{kb})$ of linkage disequilibrium is shared across populations in patients with the BBS1 M390R mutation (34). Although identification of shared haplotypes in affected individuals is potentially a powerful approach for identifying genes involved in complex disorders, one must be cautious when using this approach. For example, three different BBS mutations were found on a rare Puerto Rican haplotype, a finding suggesting a bias for mutational events on some haplotypes or a change in the Puerto Rican population structure over time $(32,34)$. Furthermore, a 6-kb deletion mutation was identified in the $B B S 4$ gene in unrelated families. This mutation seems to be recurrent because the mutation is found on different genetic backgrounds in two different families. The recurrence of this mutation is due to unequal crossing over between Alu sequences within this gene (31). This finding illustrates that local sequence context can result in recurrence of identical mutations in unrelated individuals and on different haplotypes. This finding is relevant to the study of complex diseases because it suggests that some disorders may occur commonly as a result of mutational events that recur relatively often in a population as a result of local genomic sequence and architecture.

Mutation analysis of the $B B S 2, B B S 4$, and $B B S 6$ genes led to the hypothesis that three mutant alleles are required for manifestation of the BBS phenotype, a form of complex inheritance referred to as triallelic (8). To investigate the potential for complex inheritance of BBS, we have sequenced the known BBS genes, including the recently identified $B B S 1$ gene, in a large patient cohort $(32,34)$. Our data indicate that BBS displays autosomal recessive inheritance. However, reports of rare instances of BBS nonpenetrance are consistent with complex inheritance in a small subset of patients $(8-10)$. Importantly, the existence of inter- and intrafamilial clinical variation indicates that there are genes that modify the BBS phenotype $(16,18,35-37)$. Genetic modifiers of the BBS phenotype may be the other BBS genes and/or genes that encode products that interact with BBS proteins.

Improved studies of complex disease. The identification of genes involved in common complex diseases has proved to be difficult. Improved and refined strategies need to be used to facilitate identification of genes and sequence variation involved in such disorders. Such strategies include 1) investigation of the influence of local genomic architecture on recurrent mutation, 2) evaluation of the contribution of gene dosage differences (increased and decreased) to disease phenotypes, and 3) determination of the influence on gene expression of noncoding evolutionary-conserved sequences. Thus, in pursuit of genes and genetic variation involved in complex disorders, we will need to take into account genomic architecture, local sequence context, and genome annotation in the evaluation of candidate genes and include the use of methods for identifying recurrent mutations, gene dosage variation, and variation in noncoding sequences. Furthermore, the identification of the genes that cause Mendelian disorders such as BBS provides the opportunity to identify genes that mitigate or modify phenotypes generally thought to be monogenic in origin. Continued study of Mendelian disorders and their modifier may provide the best opportunity for improved understanding of genetic complexity.

BBS animal models. The identification of modifier genes for even monogenic disorders is difficult in humans. The use of animal models is a powerful resource for the identification of modifier genes. In preliminary work, we have developed zebrafish and mouse models of BBS and are in the process of careful phenotypic evaluation of these models. Such animal models will allow studies to determine whether BBS genes modify each other and the opportunity to use genetic methods to identify other loci that genetically interact with the known BBS genes. Furthermore, these models will facilitate function studies of the BBS proteins and the further study of BBS pathophysiology.

Acknowledgments. I thank the numerous members of the laboratory who have contributed to this work, including G. Beck, J. Beck, T. Braun, K.E. Bugge, N. Haider, A. KwitekBlack, K. Mykytyn, D. Nishimura, C.C. Searby, M. Shastri, L.M. Streb, R. Swiderski, H.-J. Yen, and L. Ying. I also thank the following individuals without whom this work would not have been accomplished: Drs. L.G. Biesecker, R. Carmi, T. Casavant, SC Chandrasekharappa, A.S. Cornier, G.F. Cox, D.M. Duhl, K. Elbedour, A.B. Fulton, J.R. Heckenlively, E. Heon, A. Iannaccone, S.G. Jacobson, R. Riise, A. RaasRothschild, E.M. Stone, R.G. Weleber, and A.F. Wright.

\section{REFERENCES}

1. Kwitek-Black AE, Carmi R, Duyk GM, Buetow JH, Elbedour K, Parvari R, Yandava CN, Stone EM, Sheffield VC 1993 Linkage of Bardet-Biedl syndrome to chromosome $16 \mathrm{q}$ and evidence for non-allelic genetic heterogeneity. Nat Genet 5:392-396

2. Leppert M, Baird L, Anderson KL, Otterud B, Lupski JR, Lewis RA 1994 BardetBiedl syndrome is linked to DNA markers on chromosome 11q and is genetically heterogeneous. Nat Genet 7:108-112

3. Sheffield VC, Carmi R, Kwitek-Black A, Rokhlina T, Nishimura D, Duyk GM, Elbedour K, Sunden SL, Stone EM 1994 Identification of a Bardet-Biedl syndrome locus on chromosome 3 and evaluation of an efficient approach to homozygosity mapping. Hum Mol Genet 3:1331-1335

4. Carmi R, Rokhlina T, Kwitek-Black AE, Elbedour K, Nishimura D, Stone EM, Sheffield EM 1995 Use of a DNA pooling strategy to identify a human obesity syndrome locus on chromosome 15. Mol Genet 4:9-13

5. Young T-L, Penney L, Woods MO, Parfrey PS, Green JS, Hefferton D, Davidson WS 1999 A fifth locus for Bardet-Biedl syndrome maps to chromosome 2q31. [letter] Am J Hum Genet 64:901-904

6. Woods MO, Parfrey PS, Green JS, Davidson WS 2000 Evidence for yet another novel Bardet-Biedl syndrome (BBS) locus in the Newfoundland population. [abstract] Am J Hum Genet 67(suppl): 1730

7. Beales PL, Katsanis N, Lewis RA, Ansley SJ, Elcioglu N, Raza J, Woods MO, Green JS, Parfrey PS, Davidson WS, Lupski JR 2001 Genetic and mutational analyses of a large multiethnic Bardet-Biedl cohort reveal a minor involvement of BBS6 and delineate the critical intervals of other loci. Am J Hum Genet 68:606-616 
8. Katsanis N, Ansley SJ, Badano JL, Eichers ER, Lewis RA, Hoskins BE, Scambler PJ, Davidson WS, Beales PL, Lupski JR 2001 Triallelic inheritance in Bardet-Biedl syndrome, a mendelian recessive disorder. Science 293:2256-2261

9. Katsanis N, Eichers ER, Ansley SJ, Lewis RA, Kayserili H, Hoskins BE, Scambler PJ, Beales PL, Lupski JR 2002 BBS4 is a minor contributor to Bardet-Biedl syndrome and may also participate in triallelic inheritance. Am J Hum Genet 71:22-29

10. Beals PL, Badano JL, Ross AJ, Ansley SJ, Hoskins BE, Kirsten B, Mein CA, Froguel P, Scambler PJ, Lewis RA, Lupski JR, Katsanis N 2003 Genetic interaction of BBS mutations with alleles at other BBS loci can result in non-Mendelian Bardet-Bied syndrome. Am J Hum Genet 72:1187-1199

11. Laurence JZ, Moon RC 1866 Four cases of retinitis pigmentosa occurring in the same family and accompanied by general imperfection of development. Ophthalmol Rev $2: 32-41$

12. Bardet G 1920 Sur un syndrome d'obesite infantile avec polydactylie et retinite pigmentaire (contribution a l'etude des formes cliniques de l'obesite hypophysaire). Thesis, Paris, Note no. 479

13. Biedl A 1922 Ein Geschwisterpaar mit adiposo-genitaler Dystrophie. Dtsch Med Wschr 48:1630

14. Ammann F 1970 Investigations cliniques et genetiques sur le syndrome de BardetBiedl en Suisse. J Genet Hum 18(suppl):1-310

15. Alton DJ, McDonald P 1973 Urographic findings in Laurence-Moon-Biedl syndrome. Radiology 109:659-663

16. Green JS, Parfrey PS, Harnett JD, Farid NR, Cramer BC, Johnson G, Health O, McManamon PJ, O’Leary E, Pryse-Phillips W 1989 The cardinal manifestations a Bardet-Biedl syndrome, a form of Laurence-Moon-Biedl syndrome. N Engl J Med 321:1002-1009

17. Harnett JD, Green JS, Cramer BC, Johnson G, Chafe L, McManamon P, Farid NR, Pryse-Phillips W, Parfrey PS 1988 The spectrum of renal disease in Laurence-MoonBiedl syndrome. N Engl J Med 319:615-618

18. Elbedour K, Kucker N, Zalstein E, Barki Y, Carmi R 1994 Cardiac abnormalities in the Bardet-Biedl syndrome: echocardiographic studies of 22 patients. Am J Med Genet 52:164-169

19. Farag TI, Teebi AS 1989 High incidence of Bardet-Biedl syndrome among the Bedouin. [letter] Clin Genet 36:463-465

20. Carmi R, Elbedour K, Wietzman D, Sheffield V, Shoham-Vardi I 1998 Lowering the burden of hereditary diseases in a traditional, inbred community: ethical aspects of genetic research and its application. Sci Context 11:391-394

21. Slavotinek AM, Stone EM, Mykytyn K, Heckenlively JR, Green JS, Heon E, Musarella MA, Parfrey PS, Sheffield VC, Biesecker LG 2000 Mutations in MKKS cause Bardet-Biedl syndrome. Nat Genet 26:15-16

22. Katsanis N, Beales PL, Woods MO, Lewis RA, Green JS, Parfrey PS, Ansley SJ, Davidson WS, Lupski JR 2000 Mutations in MKKS cause obesity, retinal dystrophy and renal malformations associated with Bardet-Biedl syndrome. Nat Genet 26:67-70

23. Badano JL, Ansley SJ, Leitch CC, Lewis RA, Lupski JR, Katsanis N 2003 Identification of a novel Bardet-Biedl syndrome protein, BBS7, that shares structural features with BBS1 and BBS2. Am J Hum Genet 72:650-658

24. Ansley SJ, Badano JL, Blacque OE, Hill J, Hoskins BE, Leitch CC, Kim JC, Ross AJ, Eichers ER, Teslovich TM, Mah AK, Johnsen RC, Cavender JC, Lewis RA, Leroux
MR, Beales PL, Katsanis N 2003 Basal body dysfunction is a likely cause of pleiotropic Bardet-Biedl syndrome. Nature 425:628-633

25. Tayel SM, Al-Naggar RL, Krishna Murthy DS, Naguib KK, Al-Awadi SA 1999 Familial pericentric inversion of chromosome 1 (p36.3q23) and Bardet-Biedl syndrome. J Med Genet 36:418-419

26. Slavotinek AM, Biesecker LG 2000 Phenotypic overlap of McKusick-Kaufman syndrome with Bardet-Biedl syndrome: a literature review. Am J Med Genet 95:208 215

27. Robinow M, Shaw A 1979 The McKusick-Kaufman syndrome: recessively inherited vaginal atresia, hydrometrocolpos, uterovaginal duplications, anorectal anomalies, postaxial polydactyly, and congenital heart disease. J Pediatr 94:776-777

28. Stone DL, Agarwala R, Schaffer AA, Weber JL, Vaske D, Oda T, Chandrasekharappa SC, Francomanono CA, Biesecker LG 1998 Genetic and physical mapping of the McKusick-Kaufman syndrome. Hum Mol Genet 7:475-481

29. Stone DL, Slavotinek A, Bouffard GG, Banerjee-Basu S, Baxevanis AD, Barr M, Biesecker LG 2000 Mutation of a gene encoding a putative chaperonin causes McKusick-Kaufman syndrome. Nat Genet 25:79-82

30. Nishimura DY, Searby CC, Carmi R, Elbedour K, Van Maldergem L, Fulton AB Lam BL, Powell BR, Swiderski RE, Bugge KE, Haider NB, Kwitek-Black AE, Ying L, Duhl DM, Gorman SW, Heon E, Iannaccone A, Bonneau D, Biesecker G, Jacobson SG, Stone EM, Sheffield VC 2001 Positional cloning of a novel gene on chromosome 16q causing Bardet Biedl syndrome (BBS2). Hum Mol Genet 10:864-874

31. Mykytyn K, Braun T, Carmi R, Haider NB, Searby CC, Shastri M, Beck G, Wright AF, Iannaccone A, Elbedour K, Riise R, Baldi A, Raas-Rothchild A, Gorman SW, Duhl DM, Jacobson SG, Stone EM, Sheffield VC 2001 Identification of a gene that, when mutated, causes the human obesity syndrome BBS4. Nat Genet 28:188-191

32. Mykytyn K, Nishimura DY, Searby CC, Shastri M, Yen H-J, Beck JS, Braun T, Streb LM, Cornier AS, Cox GF, Fulton AB, Carmi R, Luleci G, Chandrasekharappa SC, Collins FS, Jacobson SG, Heckenlively JR, Weleber RG, Stone EM, Sheffield VC 2002 Identification of the gene most commonly involved in Bardet-Biedl syndrome (BBS1), a complex human obesity syndrome. Nat Genet 31:435-438

33. Merz AJ, So M, Sheetz MP 2000 Pilus retraction powers bacterial twitching motility. Nature 407:98-102

34. Mykytyn K, Nishimura DY, Searby CC, Beck G, Bugge K, Haines JL, Cornier AS, Cox GF, Fulton AB, Carmi R, Iannaccone A, Jacobson SG, Weleber RG, Wright AF, Risse R, Hennekam RCM, Luleci G, Berker-Karauzum S, Biesecker LG, Stone EM, Sheffield VC 2003 Evaluation of complex inheritance involving the most common Bardet-Biedl syndrome locus (BBS1). Am J Hum Genet 72:429-437

35. Beales PL, Elcioglu N, Woolf AS, Parker D, Flinter FA 1999 New criteria for improved diagnosis of Bardet-Biedl syndrome: results of a population survey. J Med Genet 36:437-446

36. Carmi R, Elbedour K, Stone EM, Sheffield VC 1995 Phenotypic differences among patients with Bardet-Biedl syndrome linked to three different chromosome loci. Am J Med Genet 59:199-203

37. Badano JL, Kim JC, Hoskins BE, Lewis RA, Ansley SJ, Cutler DJ, Castellan C, Beales PL, Leroux MR, Katsanis N 2003 Heterozygous mutations in BBS1, BBS2 and BBS6 have a potential epistatic effect on Bardet-Biedl patients with two mutations at a second BBS locus. Hum Mol Genet 12:1651-1659 